\title{
N-acetylcysteine+nimesulide: An association strategy aiming to prevent nimesulide-induced hepatotoxicity
}

\author{
Amanda G. Elias, ${ }^{1}$ Julia S. da Silva, ${ }^{2}$ Rafaela L. Klein, ${ }^{1}$ Francieli U. I. Amaral, ${ }^{3}$ Marcelo D. Arbo, ${ }^{4}$ Fernanda \\ M. Conte, ${ }_{5}^{5}$ Solange C. Garcia, ${ }^{4}$ Eliane Dallegrave, ${ }^{5}$ Janaine R. Martins, ${ }^{5}$ Charise D. Bertol, ${ }^{6}$ Diorges H. Setim, ${ }^{1}$ \\ Adriana C. da Motta, ${ }^{1}$ Romulo P. Barcelos, ${ }^{1,2}$ Luciana G. R. Grando ${ }^{1^{\star}}$
}

\begin{abstract}
Introduction: Nimesulide is a potent anti-inflammatory with rapid and long-lasting effects, but also with a high risk of hepatotoxicity. Objective: This work aimed to prevent nimesulide-induced hepatotoxicity through the association of nimesulide with a hepatoprotective agent. Materials and Methods: First, we tested three hepatoprotective agents: $\mathrm{N}$-acetylcysteine, L-carnitine, and Gingko biloba extract in an in vitro hepatic cell model. Both N-acetylcysteine and $G$. bilobashowed promisor results. We selected $\mathrm{N}$-acetylcysteine to continue the studies in an animal model. In vivostudy was performed using male Wistar rats divided in 4 groups: control, nimesulide (100mg/kg/day), nimesulide (100mg/kg/day) + $\mathrm{N}$-acetylcysteine $(100 \mathrm{mg} / \mathrm{kg} /$ day) and $\mathrm{N}$-acetylcysteine alone $(100 \mathrm{mg} / \mathrm{kg} /$ day). Treatments were given by gavage, daily, for 15 days. Results: Animals receiving nimesulide alone showed lower body weight gain compared to control. Body weight gain in the nimesulide $+\mathrm{N}$-acetylcysteine group was higher than nimesulide alone, evidencing lower toxicity. However, the body weight gain of the nimesulide $+\mathrm{N}$-acetylcysteine group was still lower than the control animals. Animals treated with nimesulide alone presented an increased relative mass of heart, liver, and spleen and significant hepatic damage seen in microscopy when compared to other groups. $\mathrm{N}$-acetylcysteine co-administered with nimesulide prevented the increased heart mass, but the same was not true with liver and spleen. Conclusions: This work evidence partial protection elicited by the association of $\mathrm{N}$-acetylcysteine and nimesulide against nimesulide-induced hepatotoxicity.
\end{abstract}

Keywords: Nimesulide; N-acetylcysteine; Safety; Hepatotoxicity; Anti-inflammatory.

\section{Resumo}

N-acetilcisteína + nimesulida: Estratégia de associação com o objetivo de prevenir a hepatotoxicidade induzida por nimesulida

Introdução: A nimesulida é um potente anti-inflamatório com efeitos rápidos e duradouros, mas também com alto risco de hepatotoxicidade. Objetivo: Este trabalho teve como objetivo prevenir a hepatotoxicidade induzida pela nimesulida por meio da associação de nimesulida a um hepatoprotetor. Materiais e Métodos: Primeiro, testamos três possíveis hepatoprotetores: $\mathrm{N}$-acetilcisteína, L-carnitina e
1. Graduate Program in Bioexperimentation. University of Passo Fundo, Brazil.

2. Graduate Program in Toxicological Biochemistry. Federal University of Santa Maria, Brazil.

3. Biotério. University of Passo Fundo, Brazil.

4. Graduate Program in Pharmaceutical Sciences. Federal University of Rio Grande do Sul, Brazil.

5. Federal University of Health Sciences of Porto Alegre, Brazil.

6. Graduate Program in Human Aging. University of Passo Fundo, Brazil.

*Correspondence address:

BR 285, São José

Passo Fundo, RS, Brazil.

CEP: 99052-900.

Email: rossatoluciana@upf.br

ORCID: https://orcid.org/0000-0003-4574-855X

BJHBS, Rio de Janeiro, 2020;19(2):91-99

Received on 22/07/2020. Approved on 23/11/2020.

extrato de Gingko biloba em um modelo de células hepáticas in vitro. N-acetilcisteína e G. biloba apresentaram bom potencial hepatoprotetor. Selecionamos a $\mathrm{N}$-acetilcisteína para continuar os estudos em um modelo animal. O estudo in vivo foi realizado com ratos Wistar machos divididos em 4 grupos: controle, nimesulida (100 mg/kg/dia), nimesulida $(100 \mathrm{mg} / \mathrm{kg} / \mathrm{dia})+\mathrm{N}$-acetilcisteína $(100 \mathrm{mg} / \mathrm{kg} /$ dia $)$ e N-acetilcisteína isolada $(100 \mathrm{mg} / \mathrm{kg} / \mathrm{dia})$. Os tratamentos foram realizados por gavagem, diariamente, por 15 dias. Resultados: Os animais que receberam nimesulida isoladamente apresentaram menor ganho de peso corporal em comparação ao controle. O ganho de peso corporal no grupo nimesulida $+\mathrm{N}$-acetilcisteína foi maior que o nimesulida isolado, evidenciando menor toxicidade. No entanto, o ganho de peso corporal do grupo nimesulida $+\mathrm{N}$-acetilcisteína ainda era menor do que os animais controle. Os animais tratados com nimesulida isoladamente apresentaram aumento da massa relativa do coração, fígado e baço e dano hepático significativo observado na microscopia quando comparados a outros grupos. A N-acetilcisteína co-administrada com nimesulida impediu o aumento da massa cardíaca, mas tal fato não ocorreu com o fígado e o baço. Conclusões: Este trabalho evidencia proteção parcial provocada pela associação 
de $\mathrm{N}$-acetilcisteína e nimesulida contra hepatotoxicidade induzida por nimesulida.

Descritores: Nimesulide; N-acetilcisteína; Segurança; Hepatotoxicidade; Anti-inflamatório.

\section{Resumen}

N-acetilcisteína + nimesulida: Una estrategia de asociación dirigida a prevenir la hepatotoxicidad inducida por nimesulida

Introducción: La nimesulida es un potente antiinflamatorio con efectos rápidos y duraderos, pero también con un alto riesgo de hepatotoxicidad. Objetivo: Este estudio tuvo como objetivo prevenir la hepatotoxicidad inducida por nimesulida combinando nimesulida con un medicamento hepatoprotector. Materiales y métodos: Primero, probamos tres candidatos: $\mathrm{N}$-acetilcisteína, L-carnitina y extracto de Gingko biloba en un modelo de células hepáticas in vitro. $\mathrm{N}$-acetilcisteína y G. biloba mostraron buen potencial. A continuación, seleccionamos $\mathrm{N}$-acetilcisteína para continuar los estudios en un modelo animal. El estudio in vivo se realizó con ratas Wistar machos divididas en 4 grupos: control,

\section{Introduction}

Non-steroidal anti-inflammatory drugs (NSAIDs) reduces inflammation, pain, and fever processes by decreasing the synthesis of prostaglandins by blocking cyclooxygenases. ${ }^{1,2}$ Nimesulide is a NSAID marketed for the first time in Italy, in 1985, and now it is present in more than 50 countries. In some joint diseases such as osteoarthritis and arthrosis nimesulide is a more effective alternative than other NSAIDs because it presents faster and long-lasting analgesic effect. ${ }^{3,4}$

Easy access to NSAIDs contributes to the occurrence of adverse effects related to these drugs. ${ }^{1,5,6}$ NSAIDs, along with antibiotics, are the most common cause of drug-induced hepatotoxicity, being responsible for about $10 \%$ of the cases. ${ }^{7}$ Clinical manifestations of NSAIDs- induced hepatotoxicity vary between low aminotransferase increases until fulminant hepatitis with a high mortality rate. ${ }^{8}$

The World Health Organization registered more than 320 cases of nimesulide-induced hepatotoxicity a year. These hepatic disturbances related to nimesulide raise concern about its safety profile. In 2002, the Spanish Agency for Medicines and Health Products suspended nimesulide due to high hepatotoxic risks. Ten years later, the European Medicine Agency declared that nimesulide presents a nimesulida (100 mg/kg/día), nimesulida (100 mg/kg/día) + $\mathrm{N}$-acetilcisteína (100 mg/kg/día) y N-acetilcisteína aislada (100 mg/kg/día). Los tratamientos se realizaron por sonda, diariamente, durante 15 días. Resultados: Los animales que recibieron nimesulida sola mostraron menos aumento de peso corporal en comparación con el control. El aumento de peso corporal en el grupo de nimesulida $+\mathrm{N}$-acetilcisteína fue mayor que el de nimesulida sola, mostrando menos toxicidad. Sin embargo, el aumento de peso corporal del grupo nimesulida $+\mathrm{N}$-acetilcisteína fue aún menor que el de los animales de control. Los animales tratados con nimesulida sola mostraron un aumento en la masa relativa del corazón, el hígado y el bazo y un daño hepático significativo observado al microscopio en comparación con otros grupos. La $\mathrm{N}$-acetilcisteína administrada conjuntamente con nimesulida evitó el aumento de la masa cardíaca, pero no sucedió lo mismo con el hígado y el bazo. Conclusiones: Este trabajo muestra una protección parcial causada por la asociación de N-acetilcisteína y nimesulida contra la hepatotoxicidad inducida por la nimesulida.

Palabras clave: Nimesulida; N-acetilcisteína; La seguridad; Hepatotoxicidad; Antiinflamatorio.

higher risk to induce hepatotoxicity when compared to other NSAIDs. ${ }^{9}$ Nimesulide was never approved in the USA, United Kingdom, Canada, and New Zeeland. ${ }^{9}$ Considering Latin America, Argentina suspended nimesulide in all forms of presentation while in Brazil is widely prescribed and only contraindicated to children under 12 years old because of Reye Syndrome risk. ${ }^{9}$

Mechanisms related to nimesulide-induced hepatotoxicity are not fully understood. It might involve an increased rate of nimesulide retention in the hepatobiliary compartment, adducts formed after metabolism that causes cell injury, and the inhibition of mitochondrial function with consequent oxidative stress and ATP depletion. ${ }^{10,11}$

This work aimed to enhance nimesulide safety profile through the association with a hepatoprotective agent. We tested three different candidates in vitro: $\mathrm{N}$-acetylcysteine (potent antioxidant and glutathione precursor, well known as an antidote to hepatic intoxication related to other drugs), ${ }^{12-14} \mathrm{~L}$-carnitine (a mitochondrial function enhancer), ${ }^{15,16}$ and Ginkgo biloba extract (selected due to its natural antioxidant effects) ${ }^{17,18}$ After the selection of the best candidate in the in vitro challenge, we performed an in vivostudy. 


\section{Materials and methods}

\section{Chemicals}

Nimesulide, N-acetylcysteine, L-carnitine, Dulbecco's modified eagle's medium (DMEM) with phenol and 4,500 mg/L glucose, fetal bovine serum (FBS), sodium bicarbonate, antibiotic $(10,000 \mathrm{U} / \mathrm{mL}$ penicillin, $10,000 \mu \mathrm{g} / \mathrm{mL}$ streptomycin), trypsin, 3-(4,5-dimethyltiazol-2-il)-2,5-diphenyltetrazol bromide (MTT) and dimethyl Sulfoxide (DMSO) were purchased from Sigma-Aldrich (São Paulo, Brazil), The standardized extract of Ginkgo biloba L. (leaves, Ginkgoaceae) was obtained from Martins Bauer Group - Finzelberg GmbH \& Co. KG (Germany), according to the European Pharmacopoeia.

The extract contains between 22 and 27\% flavonoid glycosides, between 5 and $7 \%$ terpenolactones, between 2 and $6 \%$ bilobalide, between 2.8 and $3.4 \%$ ginkgolides A, B, C and at most 5 ppm of ginkgolic acids.

\section{Experimental Design}

We aim to prevent nimesulide-induced hepatotoxicity through the association with a hepatoprotective agent. We tested three possible hepatoprotective ( $\mathrm{N}$-acetylcysteine, L-carnitine, and Gingko bilobaextract) in an in vitro hepatic cell model. After the in vitro challenge, we selected the most promisor hepatoprotective to continue the study in rats. In vivostudy was performed using male Wistar rats divided into four groups: control, nimesulide, nimesulide+hepatoprotector (simultaneously administered), and hepatoprotective drug alone. Treatments were given by gavage, daily, for 15 days. Hepatotoxicity was monitored during the study. Protection was evaluated by the comparison of body weight gain, organ relative mass, and liver microscopy between groups.

\section{In vitro model: HepG2 cell culture}

The HepG2 cell line is derived from human hepatocyte carcinoma and it has been accepted as a good in vitro model to study hepatotoxicity. Cells were gently provided by Dr. Marcelo Dutra Arbo, Universidade Federal do Rio Grande do Sul (UFRGS), Brazil. Cells were cultured in $75 \mathrm{~cm}^{2}$ tissue culture flasks using DMEM supplemented with 10\% FBS and 1\% antibiotic solution. Cells were kept in a humidified 5\% $\mathrm{CO}_{2}-95 \%$ air atmosphere, at $37^{\circ} \mathrm{C}$, and the medium was replaced every 2-3 days. Cells were subcultured once 70-80\% confluence was reached.

\section{Cytotoxicity assays}

Cells were seeded at a density of 50,000 cells/plate in 96-well plates to obtain confluent monolayers in $24 \mathrm{~h}$. Nimesulide $(20 \mu \mathrm{M}, 50 \mu \mathrm{M}, 100 \mu \mathrm{M}, 250 \mu \mathrm{M}$, $500 \mu \mathrm{M}, 1 \mathrm{mM}$ and $2 \mathrm{mM}$ ) was incubated for $48 \mathrm{~h}$, in 6 replicates of 3 independent experiments. Concentration-response curves were evaluated through 3-(4,5-dimethyltiazol-2-il)-2,5-diphenyltetrazol bromide (MTT) reduction assay and neutral red uptake assay. Considering cytotoxicity results, we selected $100 \mu \mathrm{M}$ nimesulide as the working concentration. Nimesulide was co-incubated with $\mathrm{N}$-acetylcysteine $(25 \mu \mathrm{M}, 50 \mu \mathrm{M}$ and $100 \mu \mathrm{M}), \mathrm{L}$-carnitine $(100 \mu \mathrm{M})$, or Gingko biloba extract $(25 \mu \mathrm{M}, 50 \mu \mathrm{M}$ and $100 \mu \mathrm{M})$. Hepatoprotective concentrations were selected following previously described works using hepatoprotective approaches in cell models. ${ }^{14-16,19}$

Stock solutions of nimesulide were prepared in DMSO. Thus, 0.1\% DMSO in culture medium was used as vehicle control. All stock solutions were stored at $-20{ }^{\circ} \mathrm{C}$ and freshly diluted on the day of the experiment.

\section{MTT reduction assay}

Cell viability was assessed through MTT reduction assay. ${ }^{20}$ After the treatment incubation period, cell culture medium was removed, and a fresh medium containing $0.5 \mathrm{mg} / \mathrm{L}$ MTT in HBSS was added and incubated for two hours. After the formed formazan crystals were dissolved in DMSO, the absorbance was measured at $550 \mathrm{~nm}$ in a multi-well plate reader. Results were graphically presented as the percentage of cell death $v$ s. concentration.

\section{Neutral red uptake assay}

After the treatment incubation period, the medium was replaced by phosphate buffer saline containing $50 \mu \mathrm{g} / \mathrm{mL}$ neutral red. Cells were incubated at $37^{\circ} \mathrm{C}$ for two hours, allowing lysosomes from viable cells to uptake the dye. Cells were gently washed with HBSS to eliminate extracellular dye and lysed with 50\% ethanol in acetic acid solution 1\%. Absorbance was read at $540 \mathrm{~nm}$ in a multi-plate reader. The percent cell death relative to that of the control cells was used as the cytotoxicity measure..$^{20}$

\section{In vivo assay}

Animals were acclimated for two weeks before the study. Food and water were provided ad libitum; animals 
were subjected to a $12 \mathrm{~h}$ light/dark cycle, controlled room temperature $22^{\circ} \mathrm{C}\left( \pm 3^{\circ} \mathrm{C}\right)$. Experiments were approved by the Ethical Committee on the use of animals from the University of Passo Fundo (Protocol no 020/2018).

Adult male Wistar rats ( $\pm 300 \mathrm{~g}$, 8 week old) were divided into four groups (6 animals/group) and were treated by oral gavage, for 15 days. Treatment groups were control (saline solution), nimesulide group (100 $\mathrm{mg} / \mathrm{kg} /$ day), nimesulide $+\mathrm{N}$-acetylcysteine group (both administered at $100 \mathrm{mg} / \mathrm{kg} /$ day) and $\mathrm{N}$-acetylcysteine group (100 mg/kg/day).

During the experiment, body mass gain and daily clinical evaluations were performed. Systemic toxicity was evaluated through the occurrence of piloerection, dehydration, bleeding and diarrhea, motor function (tone and movement coordination), breathing (rate and depth, gasping), mucosal color (pale, cyanotic), and clinical signals of abdominal pain. ${ }^{22}$ Animals were euthanized through intraperitoneal injection of Ketamine/xylazine (100mg/kg/20mg/kg, respectively).

\section{Biochemical analysis}

Blood was collected by cardiac puncture and was used to assess serum hepatic biomarkers bilirubin, hepatic transaminases (ALT and AST), and gamma-GT, using commercial kits.

\section{Organ-target toxicity}

Organs (heart, liver, kidneys, and spleen) were removed from animals washed with saline solution and dried in order to remove residual blood. After macroscopic evaluation, organs were weighted to assess the relative mass (calculated as the percentage of the total body weight) as a toxicity parameter. ${ }^{22}$

\section{Liver microscopy}

During necropsy, two fragments from two hepatic lobes from all animals were collected and immediately kept in a solution containing buffered formalin (10\%). After fixing, liver pieces were cut and mounted in slides. Samples were stained with hematoxylin/eosin and analyzed under a light microscope.

\section{Hepatic oxidative stress evaluation}

The occurrence of oxidative stress in the liver was evaluated in hepatic tissue. Liver samples were homogenized [1:4 (m/v)] in ice-cold phosphate-buffered salinesolution, $\mathrm{pH} 7.4$, with an Ultra-Turrax homogenizer and centrifuged(3000g,10 min).22 Aliquots of supernatant were taken to assess hepatic protein levels, ${ }^{23}$ lipid peroxidation, ${ }^{24}$ and non-proteic thiols content. ${ }^{25}$

\section{Statistical analysis}

Results were presented as mean \pm standard deviation from independent experiments. Normality distribution was assessed through the Shapiro-Wilk test. Relative body mass gain was analyzed through two-way ANOVA. Statistical comparisons between groups that presented normal distribution were performed by One-Way ANOVA followed by Tukey post hoc test (organ relative weights and hepatic oxidative stress) and Kruskal-Wallis followed by Dunn's post hoc (biochemical parameters) was used to compare variables without normal distribution.

\section{Results}

\section{Hepatoprotector selection}

After analyzing the concentration-response curves of nimesulide (Figure 1), we selected the concentration of $100 \mu \mathrm{M}$ to further studies. This concentration was chosen because it kills cells around $60 \%$ when compared to control conditions, as evidenced in Figure 1.

Both N-acetylcysteine and Ginkgo biloba extract significantly protected cells from nimesulide-induced cytotoxicity, as demonstrated by both cytotoxicity assays (Figure 2). L-carnitine did not counteract nimesulide damage (Figure 2). Thus, we chose $\mathrm{N}$-acetylcys-teine to continue the study, considering significant clinical experience using this drug as an antidote to revert hepatotoxicity of other drugs such as acetaminophen.12-14

$\mathrm{N}$-acetylcysteine partially protects against nimesulide-induced toxicity

During in vivostudy, control and $\mathrm{N}$-acetylcysteine groups increased relative body weight gain similarly, evidencing the lack of systemic toxicity. Animals receiving nimesulide alone showed lower body weight gain compared to control $(\mathrm{p}<0.0001)$. Animals treated nimesulide $+\mathrm{N}$-acetylcysteine significantly increased body weight gain compared to nimesulide alone $(\mathrm{p}<0.05)$, evidencing lower toxicity obtained with this association. However, systemic toxicity was not fully antagonized because the body weight gain of the nimesulide $+\mathrm{N}$-acetylcysteine group was still lower than control animals ( $\mathrm{p}<0.001$ ) (Figure 3). 

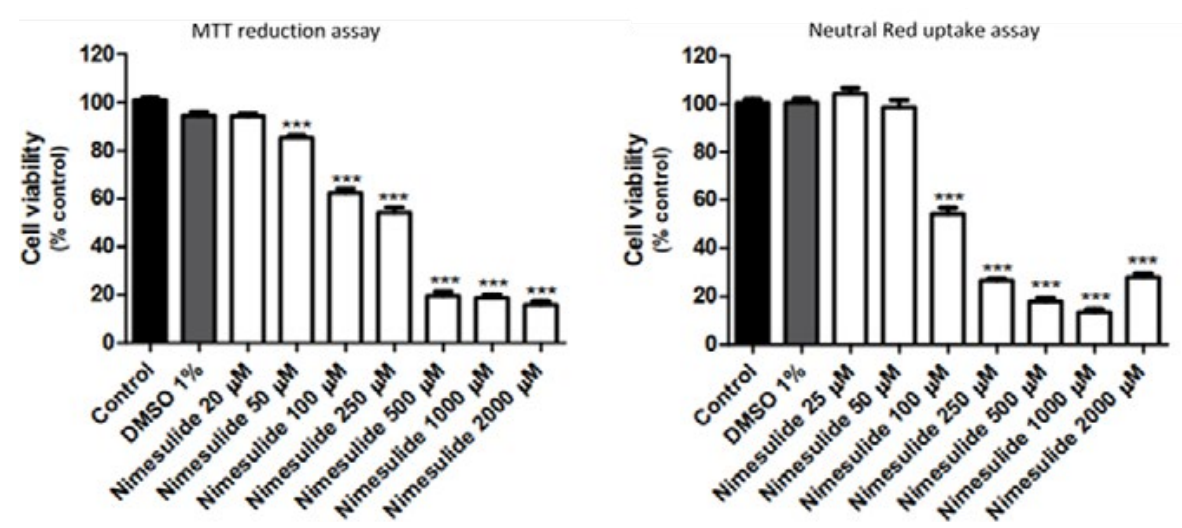

Figure 1. Effect of different concentrations of nimesulide after $48 \mathrm{~h}$ incubation at $37^{\circ} \mathrm{C}$ with HepG2 cells evaluated through A) MTT reduction assay and B) Neutral red uptake assay. Results are presented as means (\%) \pm standard deviation of 3 independent experiments. Statistical comparison were made using one-way ANOVA test followed by Tukey post hoc test $(* * * p<0.001$ vs control)

A)

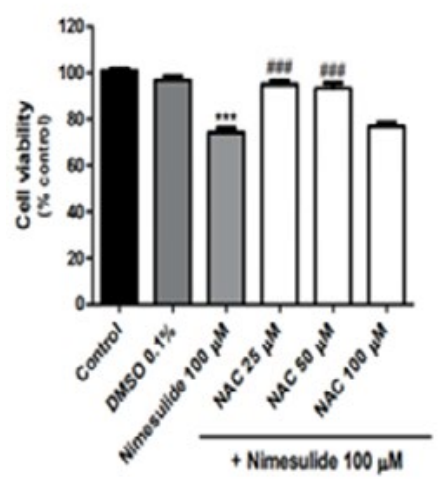

B)

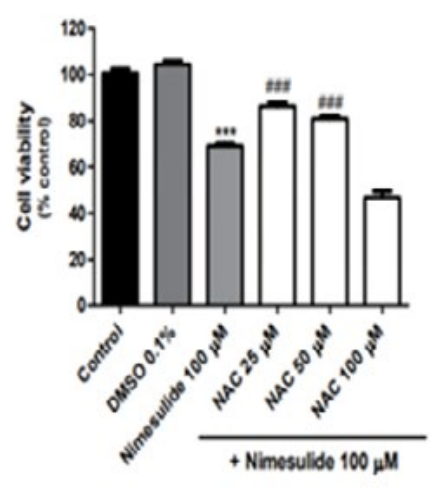

MTT reduction assay
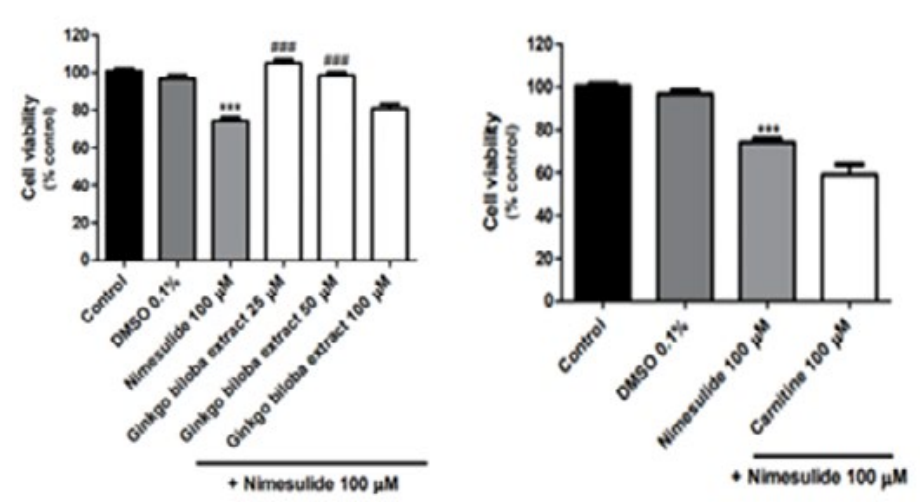

Neutral Red uptake assay

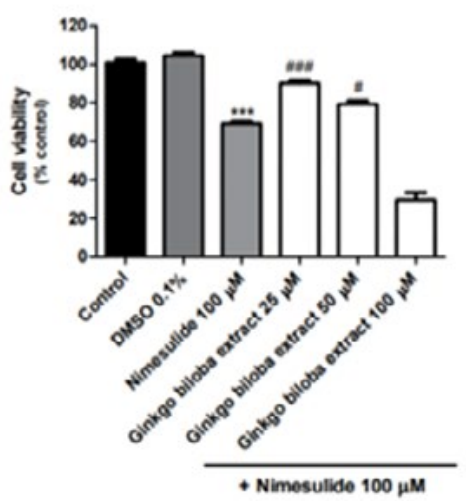

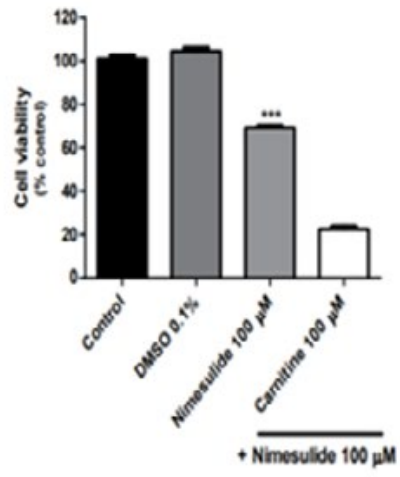

Figure 2. Citotoxicity results after co-exposure of nimesulide and 3 different hepatoprotectors after $48 \mathrm{~h}$ at $37^{\circ} \mathrm{C}$. Results are presented as means (\%) \pm standard deviation of 3 independent experiments. Statistical comparison were made using one-way ANOVA test followed by Tukey post hoc test ( $* * * p<0.001$ vs control; \#\#\# $p<0.001$ vs nimesulide group) 


\section{Original article}

Two animals from thenimesulidegroup died before the end of the study (on day 7 and day 9). Necropsy revealed hepatic changes such as degeneration, diffuse centrilobular necrosis, peritonitis, and tubular necrosis on kidneys (Figure 4).

\section{Hepatic microscopic lesions}

The typical hepatic lesions seen in nimesulide groups were hepatocellular degeneration and necrosis. Animals treated with nimesulide alone presented more significant hepatic damage than other groups and when compared to control. Despite of that, the nimesulide $+\mathrm{N}$-acetylcysteine group also showed injuries (Figure 4).

\section{Organ-target toxicity}

Nimesulide alone caused an increased relative mass of heart, liver, and spleen when compared to control groups. $\mathrm{N}$-acetylcysteine co-administered with nimesulide reverted the increased heart mass but failed to revert increased hepatic or spleen mass compared to nimesulide alone group (Figure 5). Treatments did not cause any change in the relative weight of kidneys (data not shown).

\section{Biochemical and oxidative stress results}

It was not observed significant differences between groups in biochemical biomarkers or oxidative stress parameters (hepatic lipid peroxidation, total hepatic protein level, and non-protein thiols on the liver) (data not shown).

\section{Discussion}

The major finding of this work is to evidence that $\mathrm{N}$-acetylcysteine partially reverts nimesulide-induced hepatotoxicity. We aimed to simulate the hepatotoxicity observed as an adverse effect obtained in therapeutic doses and not in anoverdose context. Thus, the selected dose would not be too far from the pharmacological dose. Then we extended treatment to 15 days. Nimesulide scheme dose regimen was also supported by previous studies in rats. ${ }^{21}$ The $\mathrm{N}$-acetylcysteine dose was selected considering hepatoprotective results observed in rats when associated with other hepato-toxicity drugs. 22

$\mathrm{N}$-acetylcysteine was selected as the most promising hepatoprotective drug after in vitrostudies. Cytotoxicity results demonstrate that both $\mathrm{N}$-acetylcysteine and $G$. biloba extract revert cell death obtained with nimesulide alone. We invested in N-acetylcysteine to continue in vivo studies considering the clinical experience and consolidated studies using this antidote in the hepatotoxicity of other drugs such as acetaminophen..$^{27-30}$ After being absorbed, $\mathrm{N}$-acetylcysteine is biotransformed by acetyltransferases to L-cysteine, which is subtract to glutathione synthesis. Thus, $\mathrm{N}$-acetylcysteine presents a direct free species scavenger effect and also acts as a glutathione precursor, being recognized as a board antioxidant. ${ }^{13,14,31}$ This mechanism may contribute to protective results against nimesulide-induced oxidative stress..$^{10,11}$

In the in vivostudy, N-acetylcysteine partially protected animals treated with nimesulide, as demonstrated

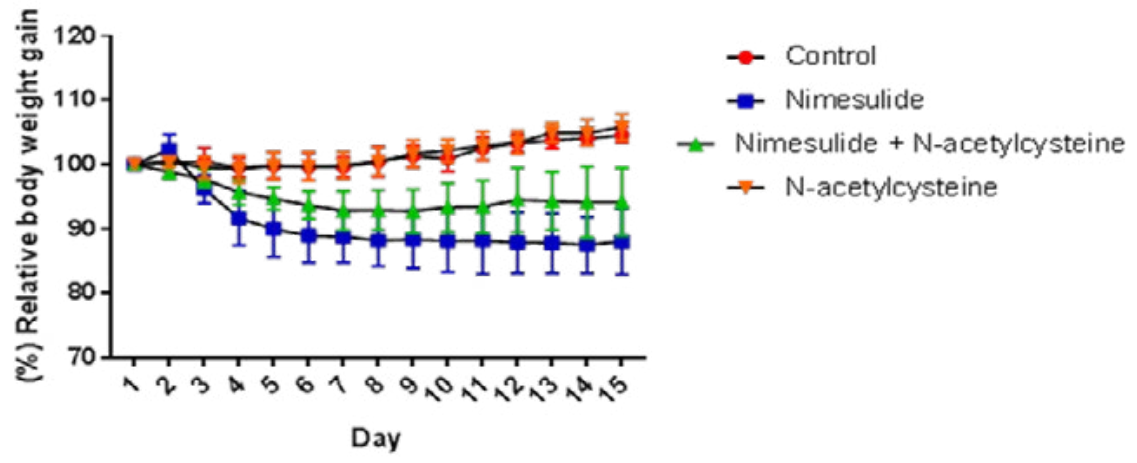

Figure 3. Relative body weight gain. Results are presented as mean \pm standard deviation. Significant results were seen between nimesulide $(100 \mathrm{mg} / \mathrm{kg})$ and control groups and nimesulide $(100 \mathrm{mg} / \mathrm{kg})$ and nimesulide $(100 \mathrm{mg} / \mathrm{kg})+\mathrm{N}-\mathrm{acetyl}-$ cysteine $(100 \mathrm{mg} / \mathrm{kg})$ groups $(p<0.05)$ 

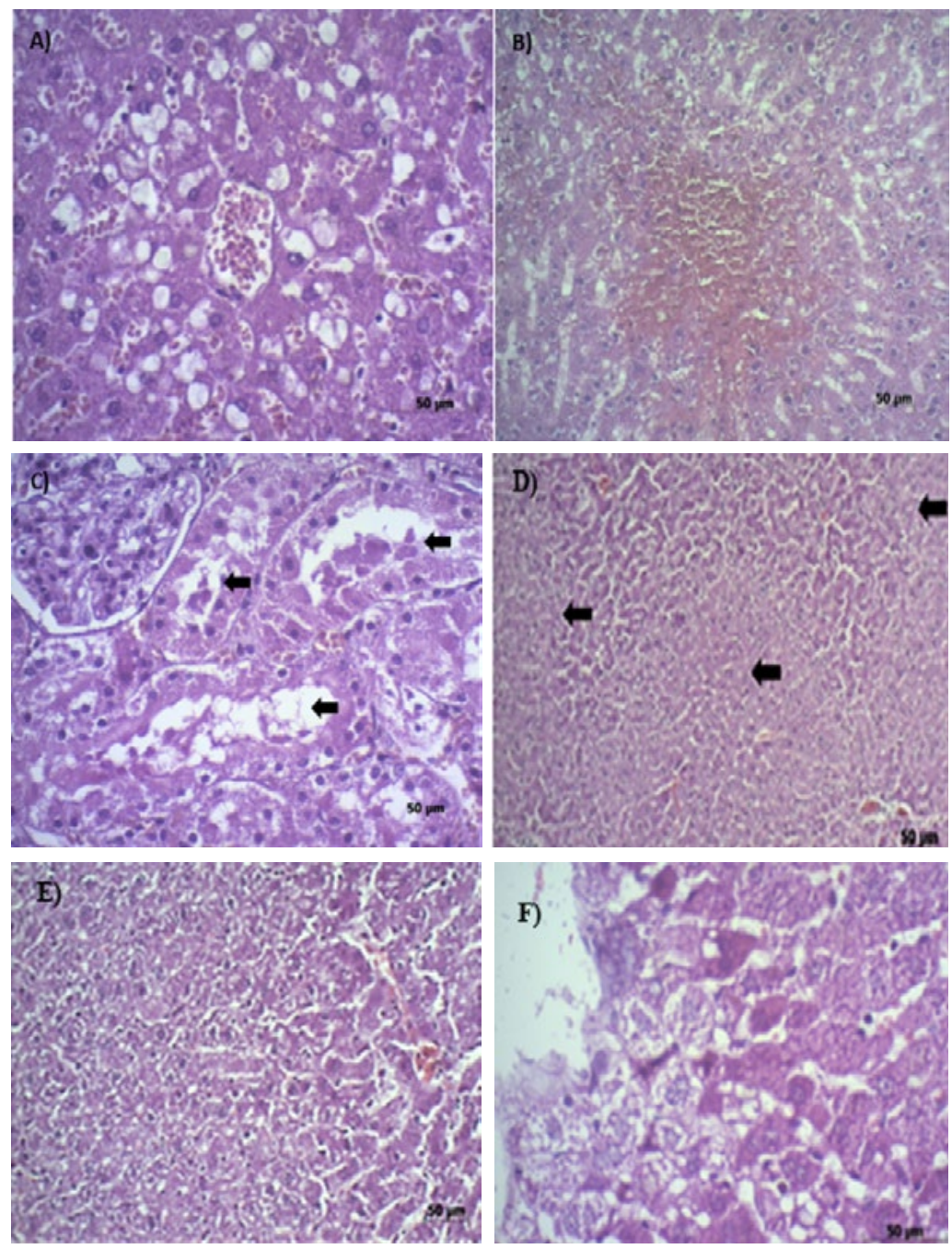

Figure 4. A), B) e C) Liver from nimesulide treated rat died on day 7. A) Hepatic centrolobullar region showing degeneration and necrosisHE, 400X B). Hepatic centrolobullar region showing degeneration and hemorrhagic necrosis. HE, 200X. C) Kidney, córtex, showing degeneration and tubular necrosis with hyaline cylinders (arrow).HE, 400X. D) and E) Liver from nimesulide group presenting D) hepatocellular degeneration and necrosis. (arrows) HE, 100x. E) HE, 200x. F) Liver from nimesulide $+\mathrm{N}$-acetylcysteine group presenting hepatocellular degeneration and necrosis.(arrows) HE, 400x
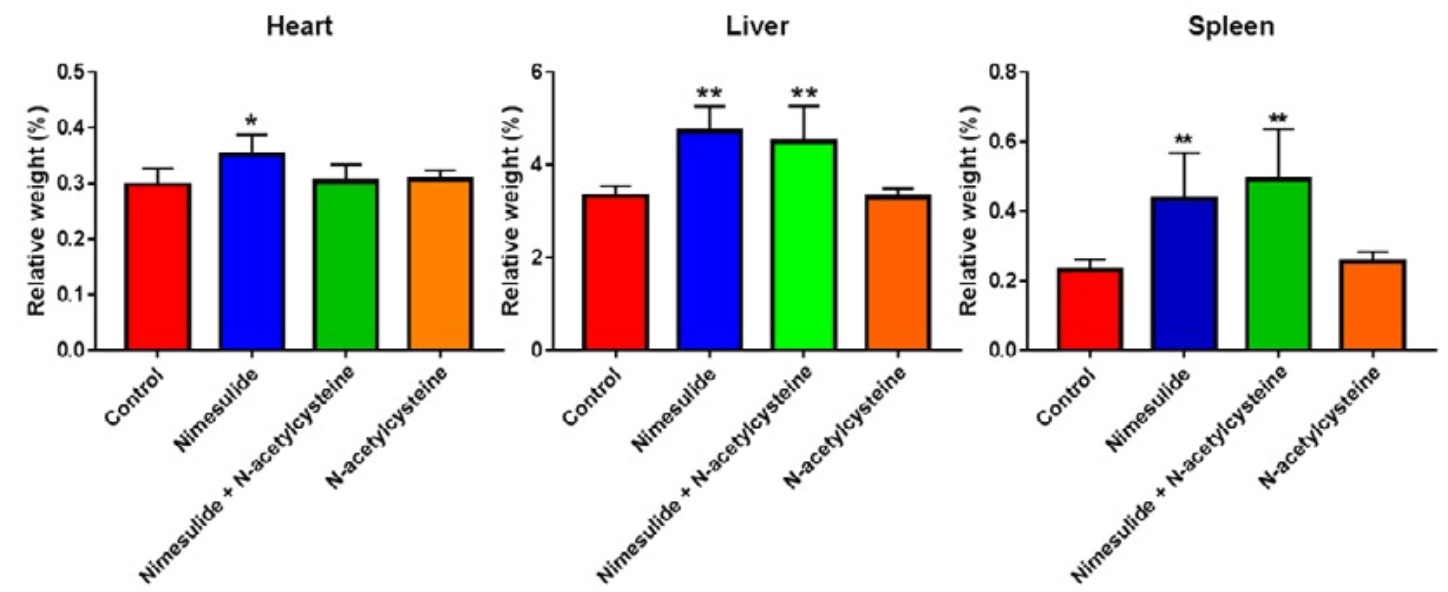

Figure 5. Relative mass of heart, liver and spleen after in vivo study. Results are presented as mean \pm standard deviation ( $N=6$ rats per group). Statistical comparison were made using one-way ANOVA test followed by Tukey post hoc test (* $p<0.05$ vs. control; $* * p<0.01$ vs. control) 
by the recovery in relative body weight gain observed in nimesulide $+\mathrm{N}$-acetylcysteine rats compared to nimesulide group. However, co-administration of $\mathrm{N}$-acetylcysteine with nimesulide was not enough to fully revert toxicity, considering body weight gain in this group is still lower than control animals. The partial protection obtained with $\mathrm{N}$-acetylcysteine is also proved in microscopic results since both groups receiving nimesulide presented hepatic lesions, but more pronounced when nimesulide is given alone.

Increases in the relative mass of livers from the nimesulide group are related to hepatocyte commitment showed in microscopy. One hypothesis to increased heart volume observed here is a secondary effect to progressive hepatic decompensation. In this scenario, blood volume is redistributed, decreasing central circulation, and increasing water retention. ${ }^{32,33}$ However, we cannot exclude a direct effect since COX-2 inhibitors are related to a higher risk of a heart attack. ${ }^{1}$

Here we did not show changes in biochemical biomarkers or hepatic oxidative stress. The absence of these expected alterations might be related to an in vivo endpoint (15 days). Apparently, 15 days is enough for cellular adaptations to restore these transient markers. This is a reliable hypothesis considering the plasticity/adaptation ability of the liver. ${ }^{34}$ Moreover, similarly to what is observed in nimesulide in humans, it seems that hepatotoxicity is strongly dependent of individual susceptibility. ${ }^{32}$ Thus, in our study, two rats treated with nimesulide alone died on days 7 and 9. The other rats, which also presented lower body weight gain and apathy, recovered until the end of the experiment. Necropsy of animals found dead revealed hepatic injury and even renal changes that deserve to be highlighted in future approaches.

$G$. biloba extract is also an excellent candidate to be employed as a hepatoprotective agent against nimesulide-induced hepatotoxicity, as suggested by our in vitro preliminary study. This extract increases prostacyclin synthesis and inhibits oxidative stress associated with inflammation. ${ }^{17}$ Flavonoids and terpenes present in this plant are related to antiapoptotic effects, which might contribute to hepatoprotection. ${ }^{17,18}$

L-carnitine does not seem to attenuate nimesulide-induced cell damage in our hepatic cell model. The mechanism of action of L-carnitine is focused on mitochondria. ${ }^{15}$ L-carnitine and acetyl-L-carnitine enhance mitochondrial function because of their key-role in $\beta$-oxidation and removal of toxic substrates from mitochondria. ${ }^{35-37}$ However, the injury caused by nimesulide involves more complex mechanisms. ${ }^{11}$

To the best of our knowledge, we show for the first time, the protection elicited by N-acetylcysteine against nimesulide-induced hepatotoxicity. Despite the excellent effects of $\mathrm{N}$-acetylcysteine used as an antidote in another drug-induced hepatotoxicity, the protection obtained here is only partial.

\section{Acknowledgments}

This work received financial support from FAPERGS (Fundação de Amparo a Pesquisa do Rio Grande do Sul), Project ARD 17/2551-000804-9.

\section{References}

1. Risser A, Donovan D, Heintzman J, et al. NSAID prescribing precautions. Am Fam Physician. 2009;80(12):1371-8.

2. Sousa JM de, Neto MF de A, et al. Ação Anti-inflamatória da Nimesulida e seu grau de Hepatotoxidade. Revista Científica do ITPAC. 2016 Feb;

3. Bianchi M, Ferrario P, Balzarini P, et al. Plasma and synovial fluid concentrations of nimesulide and its main metabolite after a single or repeated oral administration in patients with knee osteoarthritis. J Int Med Res. 2006;34(4):348-54.

4. Silva NA da, Marczyk LRS. Eficácia e tolerabilidade da nimesulida versus celecoxib na osteoartrite. Acta Ortopédica Bras. 2006;9(1):42-54

5. Adams RJ, Appleton SL, Gill TK, et al. Cause for concern in the use of non-steroidal anti-inflammatory medications in the

community -A population-based study. BMC Family Practice. 2011;12(1):70.

6. Arrais PSD, Fernandes MEP, Pizzol T da SD, et al. Prevalence of self-medication in Brazil and associated factors. Revista de Saude Publica. 2016;50(supl 2):1-11.

7. Bessone F. Non-steroidal anti-inflammatory drugs: What is the actual risk of liver damage? World J Gastroenterol. 2010;16(45):5651-61.

8. Licata A, Calvaruso V, Cappello M, et al. Clinical course and outcomes of drug-induced liver injury : Nimesulide as the first implicated medication. 2010;42:143-8.

9. OPAS. Hepatotoxicidad grave asociada con el uso de nimesulida. Bol Inf la Red Centros Inf Medicam Lat y el Caribe, Organ Pan-Americana da Saúde. 2017;(5):1-12.

10. Navarro VJ, Senior JR. Drug-related hepatotoxicity. N Engl J Med. 2006;354(7):731-9. 
11. Edited by Rainsford KD. Nimesulide - Actions and Uses. Birkhäuser Verlag, P.O. Box 133, CH-4010 Basel, Switzerland; 2005. 1-445 p.

12. Benlamkaddem S, Iken I, Houari N, et al. Paracetamol self-poisoning: When oral $\mathrm{N}$-acetylcysteine saves life? A case report. Pan Afr Med J. 2018;29:1-5.

13. Yesil Y, Ozdemir AA. Evaluation of the children with acute acetaminophen overdose and intravenous $\mathrm{N}$-acetylcysteine treatment. 2018;34(3):590-4.

14. Heil J, Schultze D, Schemmer $P$, et al. $\mathrm{N}$-acetylcysteine protects hepatocytes from hypoxia-related cell injury. Clin Exp Hepatol. 2018;4(4):260-6.

15. Masi F, Leggio B, Nanni G, et al. Effects of long-term acetyl-L-carnitine administration in rats-II: Protection against the disrupting effect of stress on the acquisition of appetitive behavior. Neuropsychopharmacology. 2003;28(4):683-93.

16. Rebouche CJ. Kinetics, pharmacokinetics, and regulation of L-carnitine and acetyl-L-carnitine metabolism. Ann N Y Acad Sci. 2004;1033:30-41.

17. Diamond BJ, Bailey MR. Ginkgo biloba. Indications, Mechanisms, and Safety. Psychiatr Clin North Am. 2013;36(1):73-83

18. Waidyanatha S, Mutlu E, Gibbs S, et al. Systemic exposure to Ginkgo biloba extract in male F344/NCrl rats: Relevance to humans. Food Chem Toxicol. 2019;131:110586.

19. Rossato LG, Costa VM, Vilas-Boas V, et al. Therapeutic concentrations of mitoxantrone elicit energetic imbalance in $\mathrm{H} 9 \mathrm{c} 2$ cells as an earlier event. Cardiovasc Toxicol. 2013;13(4):41325.

20. Arbo MD, Silva R, Barbosa DJ, et al. Piperazine designer drugs induce toxicity in cardiomyoblast h9c2 cells through mitochondrial impairment. Toxicol Lett. 2014;229(1):178-89.

21. Patel PB, Patel TK, Patni S, et al. Hepatotoxicity Studies of Nimesulide in Litters of Rat. 364001.

22. Calegari EM, Endres HC, Dallegrave E, et al. Silymarin elicits partial protection against methotrexate-induced hepatotoxicity in wistar rats. Int J Pharm Pharm Sci. 2015;7(9):462-5.

23. Bradford MM. A Rapid and Sensitive Method for the Quantitation of Microgram Quantities of Protein Utilizing the Principle of Protein-Dye Binding. 1976;254:481.

24. Ohkawa H, Ohishi N, Yagi K. Assay for lipid peroxides in animal tissues by thiobarbituric acid reaction. Anal Biochem. 1979;95(2):351-8.
25. Elmann GL. Tissue sulfhydryl groups. Arch Biochem Biophys 1959;82:70-7.

26. Raza M, Ahmad M, Gado A. A comparison of hepatoprotective activities of aminoguanidine and $\mathrm{N}$-acetylcysteine in rat against the toxic damage induced by azathioprine. 2003;134:451-6.

27. Prescott LF, Illingworth RN, Adam RD. Intravenous N-acetylcysteine : the treatment of choice for paracetamol poisoning. 1979;(November):1097-100.

28. Mumtaz K, Azam Z, Hamid S, et al. Role of N-acetylcysteine in adults with non-acetaminophen-induced acute liver failure in a center without the facility of liver transplantation. Hepatology International. 2009;3(4):563-70.

29. Al C, Gluud C, Brok J, et al. Interventions for paracetamol ( acetaminophen ) overdose (Review ) Summary of Findings for the main Comparison. Cochrane Database Syst Rev. 2018;(2):1-90.

30. Athuraliya TNC, Jones AL. Prolonged N-acetylcysteine therapy in late acetaminophen poisoning associated with acute liver failure - a need to be more cautious? Crit Care. 2009;13(3):144

31. Whillier S, Raftos JE, Chapman B, et al. Role of N-acetylcysteine and cystine in glutathione synthesis in human erythrocytes. 2013;0002.

32. Traversa G. Cohort study of hepatotoxicity associated with nimesulide and other non-steroidal anti-inflammatory drugs. BMJ. 2003;327(7405):18-22.

33. Liu H, Lee SS. Cirrhotic cardiomyopathy. Cirrhosis A Pract Guid to Manag. 2015;56(7):225-35.

34. Tao Y, Wang M, Chen E, et al. Liver Regeneration: Analysis of the Main Relevant Signaling Molecules. Mediators Inflamm. 2017;2017:4256352. doi: 10.1155/2017/4256352.

35. Tolu P, Masi F, Leggio B, et al. Effects of long-term acetyl-L-carnitine administration in rats: I. Increased dopamine output in mesocorticolimbic areas and protection toward acute stress exposure. Neuropsychopharmacology. 2002;27(3):410-20.

36. Hoang BX, Graeme Shaw D, Pham P, et al. Restoration of cellular energetic balance with I-carnitine in the neuro-bioenergetic approach for cancer prevention and treatment. Med Hypotheses. 2007;69(2):262-72.

37. Bovell DL, Clunes MT, Elder HY, et al. L-carnitine prevents increase in diastolic $[\mathrm{Ca} 2+]$ induced by doxorubicin in cardiac cells. 2000;45-8. 